\title{
Evaluation the Effect of Processing and Storage on Some of the Nutrients of Selected Varieties of Legume Sprouts in Sri Lanka
}

\author{
Prasadi De Alwis ${ }^{1}$ and Ranjani Amarakoon ${ }^{2}$
}

\begin{abstract}
Protein and anti-oxidants are some of the most important nutrients obtained from the consumption of legumes. Though sprouting enhances the nutritional value, it is important to investigate the effect of further processing of sprouts on those nutrients. Effect of germination (48 hours), hot water blanching (at $100 \pm 2^{\circ} \mathrm{C}$ for 1 minute), storage conditions $\left(10 \pm 1^{\circ} \mathrm{C}, 3 \pm 1^{\circ} \mathrm{C}, 0 \pm 0.5^{\circ} \mathrm{C}\right)$ until acceptable visual quality rating on crude protein, anti-oxidant of four legume varieties; mung (Vigna radiata), yellow cowpea (Vigna unguiculata (L.) Dhawala), red cowpea (Vigna unguiculata (L.) Waruni) and soy bean (Glycine max pb1) were investigated. The effect of pasteurization $\left(100 \pm 2^{\circ} \mathrm{C}\right.$ for 30 minutes $)$ on mung bean sprouts in brine after blanching was analysed with respect to crude protein and anti-oxidant content.

The hot water blanching at $100 \pm 2^{\circ} \mathrm{C}$ has not significantly affected on the crude protein content of mung, soy bean, yellow cowpea and red cowpea and it was $27.6 \%, 42.08 \%, 27.23 \%$ and $29.05 \%$ respectively which is more or less similar to the fresh sprouts. The anti-oxidant content of Mung (Vigna radiata) has significantly $(\mathrm{p}<0.05)$ increased from 3.82 to $5.54 \mathrm{mg}$ per $100 \mathrm{~g}$ after the germination and there is no significant $(p<0.05)$ increasing in the anti-oxidant content of soy (Glycine max pb1), yellow cowpea (Vigna unguiculata (L.) Dhawala) and red cowpea (Vigna unguiculata (L.) Waruni). Hot water blanching has significantly $(\mathrm{p}<0.05)$ decreased the anti-oxidant content from fresh sprouts to blanched sprouts; 5.54 to $4.33 \mathrm{mg}$ per $100 \mathrm{~g}$ of mung (Vigna radiata) and it is not significant $(\mathrm{p}<0.05)$ in other three varieties. The best visual quality rating was observed in the blanched sprouts stored at $0 \pm 0.5^{\circ} \mathrm{C}$ in all varieties for up to 15 days without affecting the above nutrients.

Crude protein and anti-oxidant content after pasteurization of mung bean sprouts in brine have significantly $(\mathrm{p}<0.05)$ reduced and their reduction was from $26.76 \%$ to $24.64 \%$ for crude protein and from 4.33 to $3.91 \mathrm{mg}$ per $100 \mathrm{~g}$ for anti-oxidant from the process of blanching to pasteurization. This reduction of nutrients is lower when compared to reduction from fresh sprouts to blanched sprouts. The pasteurization of sprouts in brine not only increases the safety and shelf life of sprouts, but also is effective in preserving the important nutrients of sprouts though the mild reduction of nutrients is observed when compared to application of blanching process only
\end{abstract}

Keywords - legume sprouts, blanching, storage, pasteurization, sprouts in brine, crude protein, anti-oxidant.

\section{INTRODUCTION}

In the recent past the care of the people turned towards the natural foods like fresh vegetables and fresh fruits. Sprouts also fall into this category of food and are getting popular

1,2 Department of Microbiology, Faculty of Science, University of Kelaniya, Sri Lanka. worldwide as a natural, healthy food with high quality protein and all other essential nutrients.

Nowadays, the consumption of the germinated seeds became a trend in Asia and also in Western Europe as the sprouts able to satisfy the requirements of the most of nutrients. Sprouts are high in protein (21\% to $28 \%$ ), calcium, phosphorus and certain vitamins. Sprouts have been reported to have a greater nutritional value than seeds [1].

There is a dramatic increasing of food outbreaks related to consumption of legume sprouts have been reported and the reason for the outbreaks associated with these sprouts mainly due to the mode of consumption in many countries [2]. Most of them used to consume sprouts as a fresh product rather than practicing any cooking procedures as it may cause the reduction of nutritional value of the raw sprouts. As they do not subjected in to adequate heat treatments to control the levels of pathogens present, care must be take not to allow proliferation of pathogens between the time of production and the consumption.

Regulation of the storage temperature is a prevalent way to control the initial microbial population of raw sprouts. The deviations of the proximate composition and the anti-oxidant content of sprouts during the storage at particular temperature also have to be considered as it may affect the nutritional value of the sprouts at the time of consumption.

Application of minimal thermal processing such as hot water blanching is a better option to reduce the initial microbial flora [3] associated with the raw sprouts of legumes, and to preserve the natural color and the appearance of legume sprouts. Also it has been reported by many authors that, blanching not only reduce the initial microbial load but also improve the quality of fresh product but also it retains physical quality during low temperature storage while minimize the losses of nutrients as it is a mild heat treatment. Since the most foods, especially fresh fruit and vegetables are perishable; they are subjected to alterations in their structure, composition as well as nutritional properties during storage period prior to the consumption. Most of these changes are associated with physico-chemical as well as sensory qualities and attributed to nutritional composition of food, together with the action of intrinsic and extrinsic environmental factors. Blanching followed with pasteurization is another option to prevent these alterations and also to extend the shelf life.

As the germination enhances the nutrients of legume seeds, evaluating the variation of nutritional parameters with processing plays a major role in determining the nutritional 
quality of sprouts. Accordingly, this study was aimed to evaluate the effect of blanching with storage and blanching followed by pasteurization on most important nutrients i.e. protein and anti-oxidant with storage until acceptable visual quality rating of sprouts.

\section{METHODOLOGY}

\subsection{Collection of Samples}

Raw seeds of mung (Vigna radiata), yellow cowpea (Vigna unguiculata (L.) Dhawala), (Vigna unguiculata (L.) Waruni) and soy bean (Glycine max pb1) were obtained from the Seed and Plant material Development Center, Department of Agriculture, Peradeniya, Sri Lanka, which were packed in airtight polythene bags and brought to the laboratory of University.

\subsection{Preparation of Sprouts}

Raw seeds from each variety were weighed and they were rinsed with potable water to remove debris and foreign matters. Then the seeds were soaked in water separately for 16 hours at room temperature $\left(28 \pm 2^{\circ} \mathrm{C}\right)$ and transferred into containers to facilitate the germination process and kept in dark at room temperature for 48 hours. During that period, sprouts were rinsed with potable water for every 12 hour intervals. From the total weight, half of the weight was blanched by dipping in hot water $\left(100 \pm 2^{\circ} \mathrm{C}\right)$ for 1 minute followed by immediate cooling. Both blanched and nonblanched sprouts $(25 \mathrm{~g})$ were measured and immediately packed in to low density poly ethylene bags $(10 \mathrm{~cm} \times 10 \mathrm{~cm})$ which were sterilized using alcohol $(70 \%)$ and sealed. Then they were labeled and stored at $10 \pm 1^{\circ} \mathrm{C}, 3 \pm 1^{\circ} \mathrm{C}$ and $0 \pm 0.5^{\circ} \mathrm{C}$.

\subsection{Preparation of Bottled Sprouts in Brine}

Brine solution (4\%) was prepared by using food grade $\mathrm{NaCl}$ with portable water and food grade Citric acid (1.5\%). Mung bean sprouts which subjected to blanching were immediately filled in to sterile glass bottles and the brine solution was used to fill the bottles while it was hot. Filled bottles were exhausted at $100^{\circ} \mathrm{C}$ for 10 minutes and tightened the caps. After pasteurizing at $100^{\circ} \mathrm{C}$ for 30 minutes, bottles were cooled, dried, labeled and stored at room temperature.

\subsection{Visual Quality Rating (VQR) of Processed Products}

Visual quality of both blanched and non-blanched sprouts were rated using a browning scale and a shriveling scale based on the appearance of legume sprouts during the storage period at each temperature.

\subsection{Determination of the Protein Content (Kjeldahl Method)}

Sample (1.00g) was measured and placed on cleaned digestion tube. Catalyst $\left(3.5 \mathrm{~g} \mathrm{~K}_{2} \mathrm{SO}_{4}+0.4 \mathrm{~g} \mathrm{CuSO}_{4} .5 \mathrm{H}_{2} \mathrm{O}\right)$ was added to the sample followed by conc. $\mathrm{H}_{2} \mathrm{SO}_{4}(95-98 \%$, $12 \mathrm{ml}$ ). Digestion was carried on the digester (Gerhardt) out for 60 minutes at $420^{\circ} \mathrm{C}$, recommended digestion temperature. Then it was allowed to cool for 30 minutes before transfer in to the distillation setup.
Digested sample contain in the digestion tube was diluted by adding distilled water $(30 \mathrm{ml})$ and it was placed in the distillation unit (Gerhardt-Vapodest, Germany). Titration (receiver) flask containing sulphuric acid $(0.05 \mathrm{M}, 25 \mathrm{ml})$ and a few drops of methyl red indicator was placed on the unit and safety window was closed. Sodium hydroxide solution $(45 \%$ (w/w), $45 \mathrm{ml}$ ) was allowed to dispense and steam valve was opened. Distillation was carried out for 4 minutes. Solution in the receiver flask was titrated with $\mathrm{NaOH}(0.1 \mathrm{M})$ to the end point. A blank titration was carried out [4].

\subsection{Determination of Anti-oxidant Content}

Legume sprout samples $(2.00 \mathrm{~g})$ were ground with methanol $(3 \mathrm{~mL})$ to get the extraction. Standard ascorbic acid solutions (10 ppm-100ppm) were prepared and $0.5 \mathrm{~mL}$ from each concentration were separately mixed in test tubes with phosphate buffer ( $\mathrm{pH} 6,0.2 \mathrm{M}, 2.00 \mathrm{~mL})$ and Potassium ferricyanide $(1 \%, 2.00 \mathrm{~mL})$. Then they were incubated at $50^{\circ} \mathrm{C}$ for 20 minutes and allowed to cool. Trichloro acetic acid $(10 \%, 2.00 \mathrm{~mL})$ was added to the mixture and centrifuged at $600 \mathrm{rpm}$ for 10 minutes using centrifuge (Sigma 3K30, England). Supernatant $(2.5 \mathrm{~mL})$ was taken and distilled water $(2.5 \mathrm{~mL})$ was added. Then $\mathrm{FeCl}_{3}(0.1 \%, 0.5 \mathrm{~mL})$ was added and incubated at $35^{\circ} \mathrm{C}$ for 10 minutes. Absorbance was measured at $700 \mathrm{~nm}$ against a blank using spectrophotometer (Thermo Spectronic-Genesys, U.S.A). Above procedure were followed using extracted portions $(0.5 \mathrm{ml})$ of each sample of legume sprouts in the place of standard ascorbic acid solutions [5].

\subsection{Statistical Analysis}

Data was analyzed by using ANOVA with mean separation by Tukey's pair wise comparison test and 2 sample t-test Significant differences were determined at the $p<0: 05$ level [6].

\section{RESULTS AND DISCUSSION}

\subsection{Effect of Processing and Storage on Crude Protein Content}

According to the results given in Table 1, the crude protein content of mung ( $V$. radiata), soy $(G$. max pb1), yellow cowpea ( $V$. unguiculata (L.)Dhawala) and red cowpea ( $V$. unguiculata (L.)Waruni) seeds before soaking, were determined to be $23.88 \%, 36.3 \%, 25.01 \%$ and $22.12 \%$ correspondingly. These values were more or less similar to the previously reported values by Saha [1] for mung (24.08\%), Mune [7] for red cowpea (21.95\%), Henshaw [8] for white cowpea $(25.4 \%)$. As shown in the Table 3, crude protein contents of mung ( $V$. radiata), soy $(G$. max pb1), yellow cowpea (V. unguiculata (L.)Dhawala) and red cowpea ( $V$. unguiculata (L.)Waruni) sprouts were $27.45 \%, 43.41 \%$, $27.30 \%$ and $29.30 \%$ respectively, those values were comparable with the prior investigated protein contents of mung bean reported by Mubarak [9]. As shown in the Figure 1 , the crude protein content of the sprouts after 48 hours germination has significantly $(\mathrm{p}<0.05)$ increased in four varieties of legume sprouts compare to the raw seeds. 
The increase of protein content mainly due to the use of seed components during the germination process, breakdown of complex proteins into simpler form and breakdown of nutritionally undesirable constituents [9]. The metabolism of resting seeds increase as soon as they absorb water during soaking. The complex biochemical changes that occur during hydration and sprouting lead the protein constituents being broken down by enzymes into simple compounds that are used to make new compounds. The increased hydrolytic activities of the enzymes caused by sprouting resulted in improvements in the contents of the total protein due to the disappearance of starch. The absorption of nitrate facilitates the metabolism of the nitrogenous compounds from carbohydrate reserves; thus increasing crude protein levels [7].

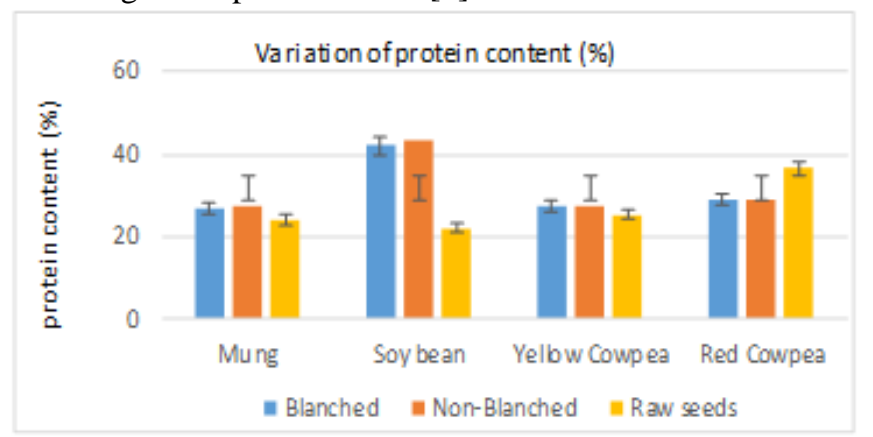

Fig. 1: Variation of the crude protein content of raw, blanched and non-blanched sprouts
As shown in the Table 1, hot water blanching process has not significantly $(\mathrm{p}<0.05)$ affected on the crude protein content of all four varieties of legume sprouts. Initial protein contents of non-blanched soy bean sprouts much higher (43.41\%) than the other varieties. When comparing with the initial protein values of all varieties, lower the storage temperature, lower the reduction of initial protein content throughout the 15 days of storage.

Microorganisms produce proteases during their growth and due to the protease activity, portion of proteins get degraded reducing measurable nitrogen content, hence the protein content may be low when storage at higher temperatures. As the storage temperature decreases, the activity of the most of the mesophilic heterotrophic organisms become slower therefore the rate of utilization of the protein by them also reduces. Therefore, the rate of utilization or the rate of decomposition of proteins decreases with the decreasing the storage temperature.

TABLE I: CRUDE PROTEIN CONTENT (\%) OF PACKED BLANCHED AND NON-BLANCHED SPROUTS PACKED IN SEALED LDPE (10×12)

\begin{tabular}{|c|c|c|c|c|c|c|c|}
\hline \multirow{2}{*}{$\begin{array}{l}\text { Days of } \\
\text { storage }\end{array}$} & \multirow[b]{2}{*}{ Variety } & \multicolumn{2}{|c|}{$\begin{array}{c}\text { Storage at } 10 \pm 1^{\circ} \mathrm{C} \\
(\%)\end{array}$} & \multicolumn{2}{|c|}{$\begin{array}{c}\text { Storage at } 3 \pm 1^{\circ} \mathrm{C} \\
(\%)\end{array}$} & \multicolumn{2}{|c|}{$\begin{array}{c}\text { Storage at } 0 \pm 0.5^{\circ} \mathrm{C} \\
(\%)\end{array}$} \\
\hline & & B & $\mathrm{NB}$ & B & NB & B & NB \\
\hline \multirow{4}{*}{$\begin{array}{l}\text { Day } 1 \\
\text { (Initial) }\end{array}$} & Mung & $26.76 \pm 0.5^{a}$ & $27.45 \pm 0.5^{\mathrm{a}}$ & $26.76 \pm 0.3^{a}$ & $27.45 \pm 0.3^{a}$ & $26.76 \pm 0.3^{a}$ & $27.45 \pm 0.3^{3}$ \\
\hline & Soy bean & $42.08 \pm 0.1^{b}$ & $43.41=0.3^{b}$ & $42.08 \pm 0.2^{b}$ & $43.41 \pm 0.3^{b}$ & $42.08 \pm 0.3^{b}$ & $43.41=0.3^{b}$ \\
\hline & Yellow Cowpea & $27.23 \pm 0.3^{a}$ & $27.30 \pm 0.2^{\mathrm{a}}$ & $27.23 \pm 0.4^{\mathrm{a}}$ & $27.30 \pm 0.3^{\mathrm{a}}$ & $27.23 \pm 0.3^{a}$ & $27.30 \pm 0.3^{3}$ \\
\hline & Red Cowpea & $29.05 \pm 0.3^{e}$ & $29.30 \pm 0.3^{e}$ & $29.05 \pm 0.3^{d}$ & $29.30=0.3^{e}$ & $29.05 \pm 0.3^{d}$ & $29.30=0.3^{e}$ \\
\hline \multirow[t]{4}{*}{ Day 8} & Mung & $24.21 \pm 0.4^{d}$ & $26.46 \pm 0.6^{d}$ & $25.22 \pm 0.6^{d}$ & $26.84 \pm 0.4^{\mathrm{a}}$ & $25.43 \pm 0.3^{d}$ & $27.18 \pm 0.3^{\mathrm{a}}$ \\
\hline & Soy bean & $40.93 \pm 0.3^{e}$ & $42.84 \pm 0.3^{b}$ & $41.82 \pm 0.3^{b}$ & $43.16 \pm 0.3^{b}$ & $42.70 \pm 0.3^{b}$ & $43.28 \pm 0.3^{b}$ \\
\hline & Yellow Cowpea & $26.17 \pm 0.7^{f}$ & $26.58 \pm 0.4^{d}$ & $27.20 \pm 0.2^{\mathrm{a}}$ & $27.24 \pm 0.3^{\mathrm{a}}$ & $27.19=0.3^{a}$ & $27.24 \pm 0.3^{\mathrm{a}}$ \\
\hline & Red Cowpea & $28.36 \pm 0.25$ & $29.18 \pm 0.2^{c}$ & $28.97 \pm 0.3^{\mathrm{c}}$ & $29.83 \pm 0.3^{\mathrm{c}}$ & $29.00 \pm 0.3^{\mathrm{c}}$ & $29.75 \pm 0.3^{\mathrm{c}}$ \\
\hline \multirow[t]{4}{*}{ Day 15} & Mung & - & - & - & - & $25.21 \pm 0.3^{d}$ & $27.10 \pm 0.3^{\mathrm{a}}$ \\
\hline & Soy bean & - & - & - & - & $42.64 \pm 0.3^{b}$ & $42.60 \pm 0.3^{b}$ \\
\hline & Yellow Cowpea & - & - & - & - & $27.10 \pm 0.3^{a}$ & $26.86 \pm 0.3^{a}$ \\
\hline & Red Cowpea & - & - & - & - & $28.84 \pm 0.3^{\mathrm{e}}$ & $28.19 \pm 0.3^{d}$ \\
\hline
\end{tabular}

The results are expressed as mean value \pm standard deviation of three replicates. Different superscript letters in same column denotes a significant difference $(\mathrm{p}<0.05)$

$\mathbf{B}=$ Sprouts subjected to blanching (at $100^{\circ} \mathrm{C}$ for 1 minute). $\mathbf{N B}=$ sprouts not subjected to blanching.

\subsection{Effect of Processing and Storage on Anti-Oxidant Content}

As shown in the Table 2, before hot water blanching the initial anti-oxidant values of mung ( $V$. radiata), soy bean $(G$. $\max \mathrm{pb} 1)$, yellow cowpea (V. unguiculata (L.)Dhawala) and red cowpea ( $V$. unguiculata (L.)Waruni) were observed as $5.33,3.07,3.81$ and $1.61 \mathrm{mg}$ per $100 \mathrm{~g}$ of sample respectively.
According to the results, hot water blanching has significantly affected $(\mathrm{p}<0.05)$ on the anti-oxidant content of mung sprouts (V. radiata) and soy bean (G. $\max \mathrm{pb} 1)$ sprouts and it was not significantly affected on the anti-oxidant content of yellow cowpea (V. unguiculata (L.)Dhawala) and red cowpea ( $V$. unguiculata (L.)Waruni). Antioxidant contents of mung ( $V$. radiata), red cowpea (V. unguiculata (L.) Dhawala) and soy bean (G. max pb1) sprouts were decreased after the hot water 
blanching while the antioxidant contents of yellow cowpea $(V$. unguiculata (L.) Dhawala) sprouts were increased after blanching.
In both blanched and non-blanched sprouts of all four varieties, anti-oxidant contents were not significantly $(\mathrm{p}<0.05)$ affected by the storage temperatures during entire period of storage (Figure 2).

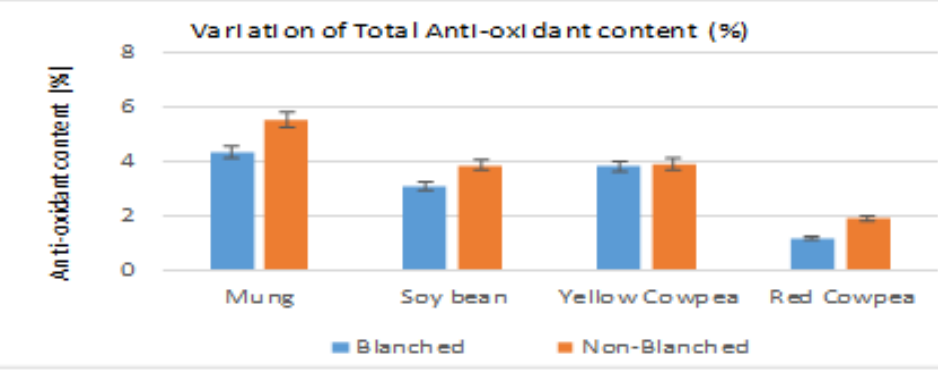

Fig. 2: Variation of Anti-oxidant content of blanched and non-blanched sprouts samples

TABLE II: TOTAL ANTI-OXIDANT CONTENT (MG PER 100G) OF BLANCHED AND NON-BLANCHED SPROUTS, PACKED IN SEALED LDPE (10×12) BAGS AND STORED AT DIFFERENT TEMPERATURES

\begin{tabular}{|c|c|c|c|c|c|c|c|}
\hline \multirow{2}{*}{$\begin{array}{l}\text { Days of } \\
\text { storage }\end{array}$} & \multirow{2}{*}{ Variety } & \multicolumn{2}{|c|}{ Storage at $10 \pm 1^{\circ} \mathrm{C}$} & \multicolumn{2}{|c|}{ Storage at $3 \pm 1^{\circ} \mathrm{C}$} & \multicolumn{2}{|c|}{ Storage at $0 \pm 0.5^{\circ} \mathrm{C}$} \\
\hline & & $\mathbf{B}$ & NB & $\mathbf{B}$ & NB & $\mathbf{B}$ & NB \\
\hline Day 1 & Mung & $4.33 \pm 0.4^{\mathrm{a}}$ & $5.54 \pm 0.3^{\mathrm{a}}$ & $4.33 \pm 0.4^{\mathrm{a}}$ & $5.54 \pm 0.3^{\mathrm{a}}$ & $4.33 \pm 0.4^{\mathrm{a}}$ & $5.54 \pm 0.3^{\mathrm{s}}$ \\
\hline \multirow[t]{3}{*}{ (Initial) } & Soy bean & $3.07 \pm 0.6^{b}$ & $3.84 \pm 0.2^{b}$ & $3.07 \pm 0.6^{b}$ & $3.84 \pm 0.2^{b}$ & $3.07 \pm 0.6^{b}$ & $3.84 \pm 0.2^{b}$ \\
\hline & Yellow Cowpea & $3.81 \pm 0.2^{\mathrm{c}}$ & $3.89 \pm 0.3^{\mathrm{c}}$ & $3.81 \pm 0.2^{\mathrm{c}}$ & $3.89 \pm 0.3^{\mathrm{c}}$ & $3.81 \pm 0.2^{\mathrm{c}}$ & $3.89 \pm 0.3^{\circ}$ \\
\hline & Red Cowpea & $1.61 \pm 0.2^{\mathrm{d}}$ & $1.88 \pm 0.4^{\mathrm{d}}$ & $1.61 \pm 0.2^{d}$ & $1.88 \pm 0.4^{d}$ & $1.61 \pm 0.2^{\mathrm{d}}$ & $1.88 \pm 0.4^{\circ}$ \\
\hline \multirow[t]{4}{*}{ Day 8} & Mung & $4.46 \pm 0.6^{\mathrm{a}}$ & $5.41 \pm 0.5^{\mathrm{a}}$ & $4.38 \pm 0.3^{\mathrm{a}}$ & $5.35 \pm 0.6^{\mathrm{a}}$ & $4.30 \pm 0.3^{\mathrm{a}}$ & $5.40 \pm 0.8^{\mathrm{a}}$ \\
\hline & Soy bean & $3.35 \pm 0.2^{b}$ & $3.76 \pm 0.5^{b}$ & $3.14 \pm 0.5^{b}$ & $3.79 \pm 0.7^{b}$ & $2.90 \pm 0.7^{b}$ & $3.76 \pm 0.5^{\mathrm{e}}$ \\
\hline & Yellow Cowpea & $3.88 \pm 0.1^{\mathrm{c}}$ & $3.80 \pm 0.4^{c}$ & $3.73 \pm 0.2^{\mathrm{c}}$ & $3.75 \pm 0.5^{c}$ & $3.84 \pm 0.5^{c}$ & $3.81 \pm 0.3^{\circ}$ \\
\hline & Red Cowpea & $1.93 \pm 0.4^{\mathrm{e}}$ & $1.85 \pm 0.2^{\mathrm{d}}$ & $1.63 \pm 0.6^{\mathrm{d}}$ & $1.80 \pm 0.2^{\mathrm{d}}$ & $1.52 \pm 0.4^{\mathrm{d}}$ & $1.82 \pm 0.2^{\circ}$ \\
\hline \multirow[t]{4}{*}{ Day 15} & Mung & - & - & - & - & $4.28 \pm 0.3^{\mathrm{a}}$ & $5.43 \pm 0.4^{\mathrm{a}}$ \\
\hline & Soy bean & - & - & - & - & $2.92 \pm 0.2^{b}$ & $3.72 \pm 0.2^{\mathrm{b}}$ \\
\hline & Yellow Cowpea & - & - & - & - & $3.79 \pm 0.4^{c}$ & $3.83 \pm 0.3^{\circ}$ \\
\hline & Red Cowpea & - & - & - & - & $1.55 \pm 0.5^{\mathrm{d}}$ & $1.79 \pm 0.2^{\circ}$ \\
\hline
\end{tabular}

The results are expressed as mean value \pm standard deviation of tree replicates. Different superscript letters in same column denotes a significant difference $(\mathrm{p}<0.05)$.

$\mathbf{B}=$ Sprouts subjected to blanching (at $100^{\circ} \mathrm{C}$ for 1 minute). $\mathbf{N B}=$ sprouts not subjected to blanching.

The anti-oxidant content of the mung bean sprouts in brine have significantly $(\mathrm{p}<0.05)$ reduced during the pasteurization process as they process under $100^{\circ} \mathrm{C}$ for longer time compared to the fresh sprouts. However, this reduction of nutrients from blanching to pasteurization is lower when compared to

TABLE III: VARIATION OF CRUDE PROTEIN CONTENT AND THE TOTAL ANTI-OXIDANT CONTENT WITH THE PROCESSING Crude protein (\% of dry weight) reduction from fresh sprouts to blanched sprouts. Different temperatures may change the mechanism of action of some antioxidants [10], the effect can be altered [11].

\begin{tabular}{|c|c|c|c|c|c|c|c|c|}
\hline \multirow[b]{2}{*}{ Variety } & \multicolumn{4}{|c|}{ Crude protein ( $\%$ of dry weight) } & \multicolumn{4}{|c|}{ Anti-oxidant (mg per 100g) } \\
\hline & Raw & $\begin{array}{c}\text { Fresh } \\
\text { Sprouts }\end{array}$ & $\begin{array}{l}\text { Blanched } \\
\text { Sprouts }\end{array}$ & $\begin{array}{l}\text { Canned } \\
\text { Sprouts }\end{array}$ & Raw & $\begin{array}{c}\text { Fresh } \\
\text { Sprouts }\end{array}$ & $\begin{array}{c}\text { Blanched } \\
\text { Sprouts }\end{array}$ & $\begin{array}{l}\text { Canned } \\
\text { Sprouts }\end{array}$ \\
\hline Mung & $23.88 \pm 0.2$ & $27.45 \pm 0.5$ & $26.76 \pm 0.5$ & $24.64 \pm 0.5$ & $3.82 \pm 0.3$ & $5.54 \pm 0.3$ & $4.33 \pm 0.4$ & $3.91 \pm 0.4$ \\
\hline Soy bean & $36.30 \pm 0.3$ & $43.41 \pm 0.3$ & $42.08 \pm 0.1$ & - & $3.22 \pm 0.2$ & $3.84 \pm 0.2$ & $3.07 \pm 0.6$ & - \\
\hline Yellow cowpea & $25.01 \pm 0.2$ & $27.30 \pm 0.2$ & $27.23 \pm 0.3$ & - & $3.51 \pm 0.3$ & $3.89 \pm 0.3$ & $3.81 \pm 0.2$ & - \\
\hline Red cowpea & $22.12 \pm 0.5$ & $29.30 \pm 0.3$ & $29.05 \pm 0.3$ & - & $1.50 \pm 0.4$ & $1.88 \pm 0.4$ & $1.61 \pm 0.2$ & - \\
\hline
\end{tabular}

The results are expressed as mean value \pm standard deviation of three replicates. 


\subsection{Effect of Processing and Storage on Visual Quality Rating}

According to the results given in the table 4, all varieties of both blanched and non-blanched sprouts stored in $10 \pm 1^{\circ} \mathrm{C}$ and
$3 \pm 1^{\circ} \mathrm{C}$ have not shown the level of acceptance (3.0) of browning scale on the $10^{\text {th }}$ day of storage while sprouts of all varieties stored in $0 \pm 0.5^{\circ} \mathrm{C}$ have shown the acceptance level up to the $15^{\text {th }}$ day of storage. In shriveling index, all varieties stored in $10 \pm 1^{\circ} \mathrm{C}, 3 \pm 1^{\circ} \mathrm{C}$ and $0 \pm 0.5^{\circ} \mathrm{C}$ have shown the acceptance level during the entire storage period.

TABLE IV: EFFECT OF STORAGE TEMPERATURE ON VQR (BROWNING AND SHRIVELING) OF BLANCHED (B) AND NON-BLANCHED (NB) SPROUTS

\begin{tabular}{|c|c|c|c|c|c|c|c|c|c|c|c|c|c|}
\hline \multirow{3}{*}{ Variety } & \multirow{3}{*}{$\begin{array}{l}\text { Days of } \\
\text { storage }\end{array}$} & \multicolumn{6}{|c|}{ Browning Index } & \multicolumn{6}{|c|}{ Shriveling Index } \\
\hline & & \multicolumn{2}{|c|}{$10 \pm 1^{\circ} \mathrm{C}$} & \multicolumn{2}{|c|}{$3 \pm 1^{\circ} \mathrm{C}$} & \multicolumn{2}{|c|}{$0 \pm 0.5^{\circ} \mathrm{C}$} & \multicolumn{2}{|c|}{$10 \pm 1^{\circ} \mathrm{C}$} & \multicolumn{2}{|c|}{$3 \pm 1^{\circ} \mathrm{C}$} & \multicolumn{2}{|c|}{$0 \pm 0.5^{\circ} \mathrm{C}$} \\
\hline & & NB & B & NB & B & NB & B & NB & B & NB & B & NB & B \\
\hline Mung & $\begin{array}{l}\text { Initial } \\
5^{\text {th }} \text { day } \\
10^{\text {th }} \text { day } \\
15^{\text {th }} \text { day }\end{array}$ & $\begin{array}{c}1.0 \\
2.5 \\
4.0 \\
-\end{array}$ & $\begin{array}{c}1.0 \\
2.1 \\
3.5 \\
-\end{array}$ & $\begin{array}{l}1.0 \\
1.9 \\
3.9 \\
4.7\end{array}$ & $\begin{array}{l}1.0 \\
1.5 \\
3.0 \\
4.0\end{array}$ & $\begin{array}{l}1.0 \\
1.3 \\
2.3 \\
3.5\end{array}$ & $\begin{array}{l}1.0 \\
1.0 \\
2.1 \\
3.2\end{array}$ & $\begin{array}{c}1.0 \\
1.7 \\
2.0 \\
-\end{array}$ & $\begin{array}{c}1.0 \\
1.2 \\
2.5 \\
-\end{array}$ & $\begin{array}{l}1.0 \\
1.2 \\
1.5 \\
2.3\end{array}$ & $\begin{array}{l}1.0 \\
1.0 \\
1.0 \\
2.0\end{array}$ & $\begin{array}{l}1.0 \\
1.0 \\
1.0 \\
1.2\end{array}$ & $\begin{array}{l}1.0 \\
1.0 \\
1.0 \\
1.2\end{array}$ \\
\hline Soy bean & $\begin{array}{l}\text { Initial } \\
5^{\text {th }} \text { day } \\
10^{\text {th }} \text { day } \\
15^{\text {th }} \text { day }\end{array}$ & $\begin{array}{c}1.0 \\
2.5 \\
3.5 \\
-\end{array}$ & $\begin{array}{c}1.0 \\
3.0 \\
4.8 \\
-\end{array}$ & $\begin{array}{l}1.0 \\
1.7 \\
3.5 \\
4.5\end{array}$ & $\begin{array}{l}1.0 \\
2.0 \\
3.6 \\
5.0\end{array}$ & $\begin{array}{l}1.0 \\
1.2 \\
2.0 \\
3.6\end{array}$ & $\begin{array}{l}1.0 \\
1.4 \\
2.4 \\
4.2\end{array}$ & $\begin{array}{c}1.0 \\
1.7 \\
3.5 \\
-\end{array}$ & $\begin{array}{c}1.0 \\
1.2 \\
2.3 \\
-\end{array}$ & $\begin{array}{l}1.0 \\
1.3 \\
2.0 \\
3.3\end{array}$ & $\begin{array}{l}1.0 \\
1.0 \\
1.5 \\
2.8\end{array}$ & $\begin{array}{l}1.0 \\
1.0 \\
1.7 \\
2.6\end{array}$ & $\begin{array}{l}1.0 \\
1.0 \\
1.6 \\
2.2\end{array}$ \\
\hline Yellow cowpea & $\begin{array}{l}\text { Initial } \\
5^{\text {th }} \text { day } \\
10^{\text {th }} \text { day } \\
15^{\text {th }} \text { day }\end{array}$ & $\begin{array}{c}1.0 \\
3.8 \\
5.0 \\
-\end{array}$ & $\begin{array}{l}1.0 \\
2.0 \\
4.0 \\
-\end{array}$ & $\begin{array}{l}1.0 \\
1.9 \\
3.8 \\
4.8\end{array}$ & $\begin{array}{l}1.0 \\
1.5 \\
3.0 \\
4.2\end{array}$ & $\begin{array}{l}1.0 \\
1.2 \\
2.4 \\
3.8\end{array}$ & $\begin{array}{l}1.0 \\
1.1 \\
1.9 \\
3.5\end{array}$ & $\begin{array}{c}1.0 \\
1.9 \\
3.4 \\
-\end{array}$ & $\begin{array}{c}1.0 \\
1.2 \\
2.6 \\
-\end{array}$ & $\begin{array}{l}1.0 \\
1.2 \\
1.4 \\
2.5\end{array}$ & $\begin{array}{l}1.0 \\
1.0 \\
1.3 \\
2.2\end{array}$ & $\begin{array}{l}1.0 \\
1.0 \\
1.2 \\
2.2\end{array}$ & $\begin{array}{l}1.0 \\
1.0 \\
1.2 \\
2.0\end{array}$ \\
\hline Red cowpea & $\begin{array}{l}\text { Initial } \\
5^{\text {th }} \text { day } \\
10^{\text {th }} \text { day } \\
15^{\text {th }} \text { day }\end{array}$ & $\begin{array}{c}1.0 \\
3.2 \\
4.9 \\
-\end{array}$ & $\begin{array}{c}1.0 \\
2.1 \\
3.8 \\
-\end{array}$ & $\begin{array}{l}1.0 \\
1.8 \\
3.9 \\
4.7\end{array}$ & $\begin{array}{l}1.0 \\
1.3 \\
2.9 \\
4.0\end{array}$ & $\begin{array}{l}1.0 \\
1.2 \\
2.6 \\
3.5\end{array}$ & $\begin{array}{l}1.0 \\
1.1 \\
1.5 \\
3.5\end{array}$ & $\begin{array}{c}1.0 \\
1.8 \\
3.4 \\
-\end{array}$ & $\begin{array}{c}1.0 \\
1.4 \\
2.5 \\
-\end{array}$ & $\begin{array}{l}1.0 \\
1.2 \\
1.9 \\
2.8\end{array}$ & $\begin{array}{l}1.0 \\
1.0 \\
1.4 \\
2.4\end{array}$ & $\begin{array}{l}1.0 \\
1.1 \\
1.5 \\
2.4\end{array}$ & $\begin{array}{l}1.0 \\
1.0 \\
1.3 \\
2.1\end{array}$ \\
\hline
\end{tabular}

The results are expressed as mean values of three replicates.

Sprouts were scored on a scale of 1 to 5 , where $1=$ no browning, $2=$ $25 \%$ browning, $3=50 \%$ browning, $4=75 \%$ browning, $5=100 \%$ browning in browning scale and $1=$ no shriveling, $2=25 \%$ shriveling, $3=50 \%$ shriveling, $4=75 \%$ shriveling, $5=100 \%$ shriveling in cotyledon or hypocotyl in shriveling scale.

\section{CONCLUSION}

The hot water blanching at $100 \pm 2^{\circ} \mathrm{C} 1$ minute has not significantly $(\mathrm{p}<0.05)$ affected on the crude protein content of mung (Vigna radiata), soy bean (Glycine max pb1), yellow cowpea (Vigna unguiculata (L.) Dhawala), red cowpea (Vigna unguiculata (L.) Waruni) and crude protein values were $27.6 \%, 42.08 \%, 27.23 \%$ and $29.05 \%$ respectively. The anti-oxidant content of mung (Vigna radiata) has significantly increased $(\mathrm{p}<0.05)$ from 3.82 to $5.54 \mathrm{mg}$ per $100 \mathrm{~g}$ after the germination and the anti-oxidant contents of all other varieties have not increased significantly by the germination. Hot water blanching has significantly $(\mathrm{p}<0.05)$ decreased the antioxidant content of mung bean (Vigna radiata) and the reduction was from 5.54 to $4.33 \mathrm{mg}$ per $100 \mathrm{~g}$. In other three varieties, anti-oxidant contents have not significantly $(\mathrm{p}<0.05)$ affected. Visual quality rating of the legume sprouts were found to be best in the blanched sprouts compared to nonblanched sprouts at $0 \pm 0.5^{\circ} \mathrm{C}$. Generally blanched legume sprouts stored at $0 \pm 0.5^{\circ} \mathrm{C}$ suitable for the consumption up to 15 days without affecting on nutritional value. Though the crude protein and anti-oxidant content after pasteurization of mung bean sprouts in brine have significantly reduced and their reduction was from 26.76 to $24.64 \%$ s for crude protein and from 4.33 to $3.91 \mathrm{mg}$ per $100 \mathrm{~g}$ for anti-oxidant from the process of blanching to pasteurization, this reduction of nutrients is lower when compared to the reduction of nutrients from fresh sprouts to blanched sprouts. The pasteurization of legume sprouts in brine not only increases the safety and shelf life of sprouts, but also it is effective in preserving the important nutrients of sprouts though the mild reduction is observed.

\section{ACKNOWLEDGEMENT}

The authors acknowledge the Department of Microbiology, Faculty of Science, University of Kelaniya for financial support for this study.

\section{REFERENCES}

[1] S.A. Shah, A. Zeb, T Masood, N Noreen, S. J. Abbas, M Samiullah, M. A. Alim and A. Muhammad, "Effects of sprouting time on biochemical and nutritional qualities of mungbean varieties," African Journal of Agricultural Research, 6(22), pp.5091-5098, 2001.

[2] A. M. Sikin, C. Zoellner and S. S. Rizvi, "Current intervention strategies for the microbial safety of sprouts," Journal of Food Protection ${ }^{\circledR}$, 76(12), pp.2099-2123, 2013. https://doi.org/10.4315/0362-028X.JFP-12-437

[3] E. M. Alexandre, D. M. Santos-Pedro, T. R. Brandão and C. L. Silva, "Influence of aqueous ozone, blanching and combined treatments on microbial load of red bell peppers, strawberries and watercress," Journal of Food Engineering, 105(2), pp.277-282, 2011. https://doi.org/10.1016/j.jfoodeng.2011.02.032

[4] J. A. Persson, "Handbook for Kjeldahl Digestion: a recent review of the classical method with improvements developed by FOSS", 2008.

[5] P. Jayanthi and P. Lalitha, "Reducing power of the solvent extracts of Eichhornia crassipes (Mart.) Solms," International journal of Pharm Pharm Sci, 3(3), pp.126-8, 2011. 
[6] S. E. Maxwell, and H. D. Delaney, Designing experiments and analyzing data: A model comparison perspective, vol. 1, Psychology Press, 2004.

[7] M. A. Mune, S. R. Minkaa and I. L. Mbome, "Chemical composition and nutritional evaluation of a cowpea protein concentrate," Global Advanced Research Journal of Food Science and Technology, 2(3), pp.35-43, 2013.

[8] F. O. Henshaw, "Varietal differences in physical characteristics and proximate composition of cowpea (Vigna unguiculata)," World Journal of Agricultural Sciences, 4(3), pp.302-306, 2008.

[9] A. E. Mubarak, Nutritional composition and antinutritional factors of mung bean seeds (Phaseolus aureus) as affected by some home traditional processes, Food Chemistry, 89(4), pp.489-495, 2008. https://doi.org/10.1016/j.foodchem.2004.01.007

[10] N. V. Yanishlieva and E. M. Marinova, Antioxidative effectiveness of some natural antioxidants in sunflower oil. Zeitschrift für LebensmittelUntersuchung und Forschung, 203(3), pp.220-223, 1996. https://doi.org/10.1007/BF01192867

[11] P. Zandi and L. Ahmadi, "Antioxidant effect of plant extracts of labiatae family," Journal of Food Science and

Technology (Mysore), 37(4), pp.436-439, 2000. 